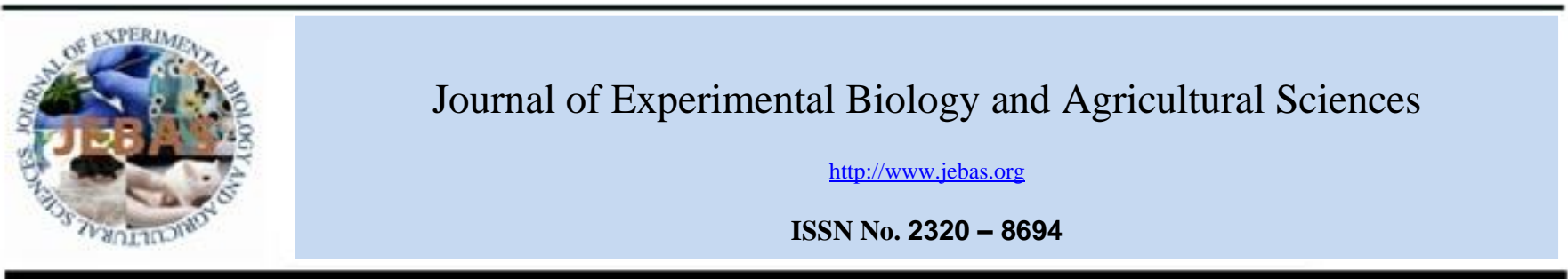

\title{
CONSTRAINTS FACED BY FARMERS IN ADOPTION OF CLIMATE RESILIENT TECHNOLOGIES
}

\author{
Yeragorla Venkata Harikrishna ${ }^{1}$, Seema Naberia ${ }^{2}$, Sudhamini Yedida ${ }^{3}$, Palaparthy Steffi ${ }^{4}$ \\ ${ }^{1}$ Department of Agricultural Extension and Communication, BACA, AAU, Anand, India \\ ${ }^{2}$ Department of Extension education, Agriculture college, JNKVV, Jabalpur, India \\ ${ }^{3}$ Department of Agricultural Extension and Communication, TNAU, Coimbatore, India \\ ${ }^{4}$ Department of Agricultural Extension and Communication, KAU, Vellayani
}

Received - December 21, 2020; Revision - June 17, 2021; Accepted - July 03, 2021

Available Online - October 20, 2021

DOI: http://dx.doi.org/10.18006/2021.9(Spl-3-NRMCSSA_2021).S364.S367

\section{KEYWORDS \\ NICRA \\ Impact on farmers \\ Andhra Pradesh}

Climate resilient technologies

* Corresponding author

E-mail: harikrishnavenkata.y@gmail.com (Y V Harikrishna)

Peer review under responsibility of Journal of Experimental Biology and Agricultural Sciences.

Production and Hosting by Horizon Publisher India [HPI] (http://www.horizonpublisherindia.in/).

All rights reserved.

\begin{abstract}
National Innovations on Climate Resilient Agriculture (NICRA) project was launched by ICAR in 2011 to develop climate-resilient agriculture technologies through strategic research. It demonstrates and reinforced to accept better practices and wide-ranging technologies for mitigating climate risk to make farming as a profitable business. The current study was carried out in the Anantapur district of Andhra Pradesh, India. The sample consists of 60 farmers as beneficiaries from NICRA villages and 60 farmers as nonbeneficiaries from non-NICRA villages were selected randomly. The ex-post facto research design was used in the study. The constraints faced by the farmers for adoption of climate resilient technologies were lack of sufficient rainfall, lack of owned resources, lack of short duration and drought tolerant crop varieties, lack of knowledge about climate resilient practices, and inadequate financial support. The key suggestions given to the respondents for implementation of climate resilient technologies are the provision of technical guidance and information should be delivered on regular basis, training programs should be conducted about climate resilient practices, financial assistance should be rendered for water and soil conservation and need based technology demonstrations should be given.
\end{abstract}

All the articles published by Journal of Experimental Biology and Agricultural Sciences are licensed under a Creative Commons Attribution-NonCommercial 4.0 International License Based on a work at www.jebas.org. 


\section{Introduction}

Climate change is one of the important aspects of concern for our country to ensure food and nutrition security to the increasing population. The impacts of climate change are worldwide, but developing countries like India are extremely vulnerable as the large proportion of the population depends on agriculture. As per the latest report, the global average temperature rise is $0.99^{\circ} \mathrm{C}$ since the pre-industrial time of 1850 (Schmidt et al., 2019). The year 2016 ranks as the warmest year, 16 of the 17 warmest years in the 136 year record all have occurred since 2001. The predicted upsurge in temperature will be in the range of 0.5 $1.2^{\circ} \mathrm{C}$ by $2020,0.88-3.16^{\circ} \mathrm{C}$ by 2050 , and $1.56-5.44^{\circ} \mathrm{C}$ by the year 2080 (IPCC 2007). Previous studies in India revealed that there are significant adverse impacts of climate change, predicted to be a decline in the yields by 4.5 to $9.0 \%$, based on the magnitude and distribution of warming. The agriculture sector is contributing about $17.4 \%$ of India's GDP, and $4.5-9.0 \%$ negative impact on production implies a cost of climate change to be roughly up to $1.5 \%$ of GDP per year. Therefore, the Government of India has accorded extra priority on research and development to deal with climate change in general and agriculture. The Prime Ministers National Action Plan over climate change has recognized agriculture as one of the 8 national missions, to encounter the challenges of sustaining domestic food production in the face of changing climate and to produce information on adaptation and mitigation in agriculture. During the XI Five year plan, ICAR started a network project 'National Initiative on Climate Resilient Agriculture' in February 2011, and in XII five-year plan, it is referred as 'National Innovations in Climate Resilient Agriculture' (NICRA).

The project targets to increase the resilience of agriculture to climate change and climate vulnerability through strategic research and technology demonstration, sponsored grants, and capacity building. The technology demonstration component and capacity building component of the NICRA project have paved the way to climate resilience in the project villages. But the extent of adoption and diffusion of climate resilient technologies in these areas is low which has led to low resilience to climate change. Countering the importance and facts in view, the present research was carried out with the objective, to explicate the constraints faced by the farmers in the adoption of climate resilient technologies and suggestions to overcome the constraints.

\section{Materials and Methods}

The present research was conducted in the Anantapur district of Andhra Pradesh during the year 2018 - 2019. This district was purposively selected because the NICRA has been implemented in this district since its inception. Chamaluru, Chakrayapeta, and Peravalli villages were selected purposively for the study, as NICRA was implemented in these selected villages of the Anantapur district. Aakuledu, Podaralla, and Siddaramapuram villages were selected under non- NICRA villages, where the program was not implemented. From each selected village, 20 respondents were selected by simple random sampling technique. The sample comprising of 60 farmers as beneficiaries from NICRA villages and 60 farmers as nonbeneficiaries from non-NICRA villages are selected randomly. Thus, making a total sample size of 120 respondents in the study. The ex-post facto research design was used in the study. The data was collected through the personal interview method.

\section{Results and Discussion}

\subsection{Constraints}

Constraints given by the respondents were operationally defined as constraints faced by the respondents for the adoption of climate resilient technologies. The respondents were inquired to express the constraints faced by them for the adoption of climate resilient technologies and the problems as stated by them were noted. Percentages and frequencies were calculated and ranking was given in the order of magnitude.

The results presented in table 1 revealed the constraints faced by the beneficiary and non-beneficiary farmers for the adoption of climate resilient technologies. The major constraints were given as lack of sufficient rainfall with a mean score of 2.66 followed by lack of owned resources (2.49), lack of short duration and drought tolerant crop varieties (2.48), lack of knowledge about climate resilient practices (2.40), inadequate financial support (2.30), resistance to change the conventional practices (2.23), poor availability of critical inputs (2.17), high labor cost (2.04), getting benefits from climate resilient technologies are not quick (2.01), lack of awareness on climate change (1.91), lack of support from the line departments (1.85) and established structures for livestock (1.75) respectively.

It is inferred that major constraints from beneficiaries are lack of sufficient rainfall, lack of owned resources, and lack of short duration and drought tolerant crop varieties. From the results of the study, it can be concluded that major constraints from nonbeneficiaries are lack of sufficient rainfall, lack of knowledge on climate resilient technologies, and lack of short duration and drought tolerant crop varieties. Results of the current study are in agreement with the findings of Jasna (2015), Archana (2017), and Dupdal \& Patil (2019) those who reported similar constraints in their study. 
Table 1 Constraints faced by the beneficiary and non-beneficiary farmers for adoption of climate resilient technologies

\begin{tabular}{|c|c|c|c|c|c|c|c|c|c|c|}
\hline \multirow[b]{2}{*}{ S.N. } & \multirow[b]{2}{*}{ Constraints } & \multicolumn{3}{|c|}{ Beneficiaries $(\mathrm{n} 1=60)$} & \multicolumn{3}{|c|}{$\begin{array}{l}\text { Non-beneficiaries } \\
(\mathrm{n} 2=60)\end{array}$} & \multicolumn{3}{|c|}{ Total $(\mathrm{N}=120)$} \\
\hline & & Score & $\begin{array}{l}\text { Mean } \\
\text { Score }\end{array}$ & Rank & Score & $\begin{array}{l}\text { Mean } \\
\text { Score }\end{array}$ & Rank & Score & $\begin{array}{l}\text { Mean } \\
\text { Score }\end{array}$ & Rank \\
\hline 1 & Lack of awareness on climate change & 121 & 2.01 & IX & 109 & 1.81 & $\mathrm{XI}$ & 230 & 1.91 & $\mathrm{X}$ \\
\hline 2 & $\begin{array}{l}\text { Lack of knowledge on climate } \\
\text { resilient technologies }\end{array}$ & 134 & 2.23 & VI & 154 & 2.56 & II & 288 & 2.4 & IV \\
\hline 3 & High labour cost & 127 & 2.11 & VII & 118 & 1.96 & IX & 245 & 2.04 & VIII \\
\hline 4 & $\begin{array}{l}\text { Lack of short duration and drought } \\
\text { tolerant crop varieties }\end{array}$ & 151 & 2.51 & III & 147 & 2.45 & III & 298 & 2.48 & III \\
\hline 5 & Poor availability of critical inputs & 129 & 2.15 & VIII & 132 & 2.20 & VI & 261 & 2.17 & VII \\
\hline 6 & Lack of support from line departments & 110 & 1.83 & $\mathrm{XI}$ & 112 & 1.86 & $\mathrm{X}$ & 222 & 1.85 & $\mathrm{XI}$ \\
\hline 7 & Lack of sufficient rainfall & 162 & 2.7 & I & 158 & 2.63 & I & 320 & 2.66 & I \\
\hline 8 & Lack of owned resources & 157 & 2.61 & II & 142 & 2.36 & IV & 299 & 2.49 & II \\
\hline 9 & $\begin{array}{l}\text { Getting benefits from climate resilient } \\
\text { technologies are not quick. }\end{array}$ & 117 & 1.95 & XI & 125 & 2.08 & VII & 242 & 2.01 & IX \\
\hline 10 & Inadequate financial support & 140 & 2.33 & $\mathrm{~V}$ & 137 & 2.28 & $\mathrm{~V}$ & 277 & 2.30 & $\mathrm{~V}$ \\
\hline 11 & $\begin{array}{l}\text { Lack of established structures for } \\
\text { livestock }\end{array}$ & 106 & 1.76 & XII & 105 & 1.75 & XII & 211 & 1.75 & XII \\
\hline 12 & $\begin{array}{l}\text { Resistance to change the conventional } \\
\text { practices }\end{array}$ & 147 & 2.45 & IV & 121 & 2.01 & VII & 268 & 2.23 & VI \\
\hline
\end{tabular}

Table 2 Suggestions given by beneficiary and non-beneficiary farmers for adoption of climate resilient technologies

\begin{tabular}{|c|c|c|c|c|c|c|c|c|c|c|}
\hline \multirow[b]{2}{*}{ S. N. } & \multirow[b]{2}{*}{ Suggestions } & \multicolumn{3}{|c|}{ Beneficiaries $(n 1=60)$} & \multicolumn{3}{|c|}{$\begin{array}{l}\text { Non-beneficiaries } \\
\quad(\mathrm{n} 2=60)\end{array}$} & \multicolumn{3}{|c|}{ Total $(\mathrm{N}=120)$} \\
\hline & & No. & $\%$ & Rank & No. & $\%$ & Rank & No. & $\%$ & Rank \\
\hline 1 & $\begin{array}{c}\text { Awareness programs should be conducted on } \\
\text { different climate resilient technologies under the } \\
\text { NICRA project }\end{array}$ & 41 & 68.33 & VIII & 50 & 83.33 & III & 91 & 75.83 & VI \\
\hline 2 & $\begin{array}{l}\text { Provision of technical information and guidance } \\
\text { should be given regularly }\end{array}$ & 56 & 93.33 & I & 53 & 88.33 & II & 109 & 90.83 & I \\
\hline 3 & $\begin{array}{l}\text { Financial assistance should be made for soil and } \\
\text { water conservation }\end{array}$ & 54 & 90.00 & II & 47 & 78.33 & V & 101 & 84.16 & III \\
\hline 4 & $\begin{array}{c}\text { Financial assistance should be made for livestock } \\
\text { development viz community grassland, fodder bank, } \\
\text { and cattle shed development etc. }\end{array}$ & 45 & 75.00 & VII & 41 & 68.33 & VIII & 86 & 71.66 & VIII \\
\hline 5 & $\begin{array}{c}\text { Training programs should be conducted on climate } \\
\text { resilient practices }\end{array}$ & 51 & 85.00 & III & 55 & 91.67 & I & 106 & 88.33 & II \\
\hline 6 & Critical inputs should be made available on time & 47 & 78.33 & $\mathrm{~V}$ & 45 & 75.00 & VI & 92 & 76.67 & V \\
\hline 7 & $\begin{array}{l}\text { Technology demonstrations should be delivered on } \\
\text { need based problems. }\end{array}$ & 49 & 81.67 & IV & 49 & 81.67 & IV & 98 & 81.67 & IV \\
\hline 8 & Follow up activities & 46 & 76.67 & VI & 42 & 70.00 & VII & 88 & 73.33 & VII \\
\hline
\end{tabular}

\subsection{Suggestions}

Suggestions of the respondents were operationally defined as the solutions given by them for the improvement in the adoption of climate resilient technologies effectively. Respondents were invited to give their suggestions to improve their adoption of climate resilient technologies, measures to overcome the existing problems faced by them in continuation of adoption. Percentages and frequencies were calculated and ranking was given in the order of magnitude.
Results presented in table 2 stated the suggestions given by beneficiary and non-beneficiary farmers for the adoption of climate resilient technologies. The majority of the respondents $(90.83 \%)$ suggested that provision of technical guidance and information should be given on regular basis, followed by the training programs should conduct on climate resilient practices $(88.33 \%)$, financial assistance should be made for water and soil conservation (84.16\%), technology demonstrations should also be given on need based problems $(81.67 \%)$, critical inputs should be made available on time $(76.67 \%)$, awareness programs should be conducted on 
different climate resilient technologies under NICRA project (75.83\%), follow up activities (73.33\%) and financial assistance should be made for livestock development viz community grassland, fodder bank, and cattle shed development (71.67\%), respectively.

It is inferred that major suggestions from beneficiaries are the provision of technical guidance and information should be given on regular basis, financial assistance should be made for water and soil conservation and training programs should be conducted on climate resilient practices. It is concluded that major suggestions from non-beneficiaries are training programs should be conducted on climate resilient technologies, provision of technical information and guidance should be given on a regular basis and awareness programs should be conducted on various climate resilient practices under the NICRA project. The present findings are in line with the research work of Charitha (2017).

\section{Conclusion}

NICRA project develops and supports the adoption of diverse improved practices and technologies for mitigating climate change to provoke agriculture as a good business. The present study accentuated the constraints confronted by the respondents in adopting the climate resilient technologies and suggestions to overcome these constraints. The major constraints are lack of sufficient rainfall, lack of owned resources, and lack of short duration and drought tolerant crop varieties. Most of the farmers suggested that provision of technical guidance and information should be given on regular basis, training programs should be conducted on climate resilient technologies and financial assistance should be made for soil and water conservation.

\section{Conflict of Interest}

The authors declare that they have no conflict of interest.

\section{References}

Archana T (2017) A study on adaptive capacity and technologies adopted by farmers for climate resilient agriculture in drought prone areas. Doctorate thesis submitted to the Professor Jayashankar Telangana State Agricultural University, Hyderadbad, India.

Charitha VG (2017) Impact of national innovations on climate resilient agriculture (NICRA) on the rural livelihood security of farmers of chikkaballapura district. M. Sc. (Agri.) thesis submitted to the University of Agricultural Sciences, Bangalore, India.

Dupdal R, Patil BL (2019) Constraints experienced and suggestions by farming community in adaptation to climate change in Karnataka: An Economic Analysis. International Journal of Current Microbiology and Applied Sciences 8(02): 376-383.

IPCC (2007) Summary for policymakers. In: Parry ML, Canziani OF, Palutikof JP, van der Linden PJ, Hanson CE (Eds.) Climate change (2007): Impacts, adaptation and vulnerability. Contribution of working group II to the fourth assessment report of the Intergovernmental Panel on Climate Change, Cambridge University Press, Cambridge, UK, Pp. 7-22.

Jasna VK (2015) Impact of climate resilient technologies in rainfed agroecosystem. M. Sc. (Agri.) Thesis (Unpublished) submitted to the Division of Agricultural Extension, IARI, New Delhi, India.

National Innovations in Climate Resilient Agriculture (NICRA), Research Highlights (2016-18). ICAR-Central Research Institute for Dryland Agriculture, Hyderabad, Pp. 128.

Schmidt LNG, Hansen J, Menne M, Persin A, Ruedy R, Zyss D (2019) Improvements in the GISTEMP uncertainty model. Journal of Geophysical Research: Atmospheres 124 (12): 6307-6326, doi:10.1029/2018JD029522. 